RESEARCH ARTICLE

\title{
Promotional Effect of Water Soluble Fertilizers on Growth and Yield of Lowland Rice
}

\author{
Bharaani Sri $\mathbf{C}^{1}$, Vasanthi $\mathrm{D}^{{ }^{*}}$, Kaleeswari R. $\mathrm{K}^{1}$, Amirtham $\mathrm{D}^{2}$ and Thavaprakaash $\mathrm{N}^{3}$ \\ ${ }^{1}$ Department of Soil Science and Agricultural Chemistry, Tamil Nadu Agricultural University, Coimbatore-641 003 \\ ${ }^{2}$ Department of Food Process Engineering, AEC \& RI, Tamil Nadu Agricultural University, Coimbatore-641 003 \\ ${ }^{3}$ Department of Agronomy, Tamil Nadu Agricultural University, Coimbatore -641 003
}

Received : 05 ${ }^{\text {th }}$ May, 2020

Revised : $27^{\text {th }}$ May, 2020

Revised : $17^{\text {th }}$ June, 2020

Accepted : $20^{\text {th }}$ June, 2020

\begin{abstract}
The present study aimed to study the effect of foliar nutrition of water-soluble fertilizers for enhancing yield and quality of rice during Kharif-2019 in clay loam soils of wetland farms, TNAU, Coimbatore. The experiment consisted of eleven treatments that include-100\% RDF combined with foliar feeding of commercially available 19:19:19 @ 1\% and 2\%, TNAU WSF 19:19:19 @ 1\% and $2 \%$, TNAU Liquid Multi Micronutrient @ 1\% either alone or in combination depending upon the treatments and absolute control. The experiment was laid out in a randomized block design (RBD) with eleven treatments replicated thrice using C0-51 rice as a test crop. The results revealed that foliar feeding of rice crop with different water-soluble fertilizers had a marked promotional effect on growth and yield of rice. Among the water-soluble fertilizers evaluated, foliar spray of TNAU water-soluble fertilizers 19:19:19 @ 2\% + TNAU Liquid Multi Micronutrient @ 1\% $\left(\mathrm{T}_{10}\right)$ concentration at active tillering, panicle initiation, 50\% flowering and harvest stage along with a recommended dose of fertilizers recorded the maximum growth (plant height (45.8, 81.2, 93.5 and $105.6 \mathrm{~cm})$, chlorophyll as SPAD value $(45.7,46.8$, 48.6 and 44.5) and LAI (3.01, 8.10, 6.72 and 3.92)) and yield attributes (number of panicles $\mathrm{m}^{-2}$ (352), number of grains panicle ${ }^{-1}$ (198) and number of filled grains panicle ${ }^{-1}(180)$ and the maximum grain and straw yield of $6233 \mathrm{~kg} \mathrm{ha}^{-1}$ and $7730 \mathrm{~kg} \mathrm{ha}^{-1}$ respectively. The promotional effect was to the tune of 113.5 percent in grain and 79.8 percent in straw yield over control. Concerning normal practice, it was a 19.7 percent increase in grain yield, and a 5.2 percent increase in straw yield was observed.
\end{abstract}

Keywords: Water soluble fertilizers; foliar fertilization; growth; yield; rice

\section{INTRODUCTION}

Cereals are the most important sources of food and nutrients in both developed and developing countries. Rice (Oryza sativa L.), a member of the family Poaceae, is the most important cereal crop and the staple food of over half the world's population and is central to the lives of billions of people around the world. India is the world's secondlargest producer of Rice (Ladha et al., 2016). Rice has the total harvested area of approximately 158 million hectares and production of more than 700 million tonnes annually (470 million tonnes of milled rice) (Ricepedia and Irri, 2018).In recent days, there is a slowdown in the rice area and yield. To meet out the demand, it is inevitable to take necessary steps to improve rice yield. Nutrient management is the most basic factor and is found to exert a great influence not only on growth and yield attributes but also for obtaining sustained productivity (Mudalagiriyappa et al., 2016). Foliar feeding of nutrients along with soil application helps in augmenting the nutritional requirements of crops. Foliar nutrition facilitates to overcome problems like immobilization, fixation, and leaching of nutrients and provides efficient nutrition for correcting deficiencies, especially for short duration crops. For foliar feeding and fertilization, recently, new generation specialty fertilizers have been introduced. Water-soluble fertilizers supply crops with optimal rates of nutrients throughout the growth cycle in the most efficient manner and without degrading soil and water resources and they have high content of primary nutrients with low salt index and high solubility. The objective of the present study was to find out the effect of foliar nutrition of water soluble fertilizers on rice yield and subsequently to standardize the concentration of foliar spray of water soluble fertilizers. 


\section{MATERIAL AND METHODS}

The field experiment was conducted during Kharif 2019 at wetland farms, TNAU, Coimbatore ( $11^{\circ}$ North Latitude, and $77^{\circ}$ East Longitude). The experimental soil belonged to the Noyyal series (Typic haplustalf) and was clay loam in texture (Piper, 1966), moderately alkaline in reaction $(\mathrm{pH}$ 8.2) (Jackson, 1973) and non - saline (EC $0.50 \mathrm{dS}$ $\mathrm{m}^{-1}$ ) (Jackson, 1973). The initial soil fertility status showed low available $\mathrm{KMnO}_{4}-\mathrm{N}\left(252 \mathrm{~kg} \mathrm{ha}^{-1}\right.$ ) (Asija and Subbiah, 1956), medium available Olsen-P (22 $\mathrm{kg} \mathrm{ha}^{-1}$ ) (Olsen, 1954) and high available $\mathrm{NH}_{4} \mathrm{OAc}-\mathrm{K}$ (600 kg ha-1) (Stanford et al., 1949) status. The experiment was conducted with the following eleven treatments viz., $\mathrm{T}_{1}$ (100\% RDF +1\% Urea + 2\% MAP $+1 \% \mathrm{KCl} \mathrm{FS}) \mathrm{T}_{2}(100 \% \mathrm{RDF}+19: 19: 19$ @ 1\% FS (Commercially available)), $\mathrm{T}_{3}(100 \% \mathrm{RDF}+19: 19: 19$ @ 2\% FS ( Commercially available)), $\mathrm{T}_{4}(100 \% \mathrm{RDF}$ + TNAU WSF 19:19:19 @ 1\% FS) T TNAU WSF 19:19:19 @ 2\% FS) $\mathrm{T}_{6}(100 \%$ RDF + TNAU Liquid multi micronutrient @ 1\% FS) T $(100 \%$ RDF + 19:19:19 @ 1\% (Commercially available) + TNAU Liquid multi micronutrient @ 1\% FS) T 8 (100\% RDF + 19:19:19 @ 2\% (Commercially available) + TNAU Liquid multi micronutrient @ 1\% FS) $\mathrm{T}_{9}$ (100\% RDF + TNAU WSF 19:19:19 @ 1\% + TNAU Liquid multi micronutrient @ 1\% FS) $T_{10}(100 \%$ RDF + TNAU WSF 19:19:19 @ 2\% + TNAU Liquid multi micronutrient @ 1\% FS) $T_{11}$ (Absolute control (WS)). Irrespective of treatments, common dosage of fertilizer based on STCR recommendation for the yield target of $8 \mathrm{t} \mathrm{ha}^{-1}$ was applied to all the plots except absolute control $\left(T_{11}\right)$. Foliar feeding was given at active tillering, panicle initiation, 50\% flowering and grain filling stages. The experiment was laid out in randomized block design (RBD) with eleven treatments replicated thrice using $\mathrm{CO}-51$ rice as a test crop. The biometric observation for its growth parameters like plant height, number of tillers $\mathrm{m}^{-2}$, leaf area index (Palaniswamy and Gomez, 1974), and chlorophyll index (using SPAD meter) were recorded at consecutive stages. The yield attributes like the number of productive tillers $\mathrm{m}^{-2}$, number of filled grains panicle ${ }^{-1}, \%$ chaffy grains, panicle length, and 1000-grain weight were recorded from the randomly labeled five plants of each plot. At the maturity stage, the net plots were harvested, and hand threshing was done manually. Then the grains were cleaned, and sun-dried. Plot-wise straw and grain yields were recorded after drying to constant weight.

\section{RESULTS AND DISCUSSION}

\section{Rice Growth}

A perusal of data depicted in Tables 1 and 2 divulged the significant influence of foliar spray of various fertilizers on plant height, chlorophyll as SPAD value, LAI, and the number of tillers hill-1 of rice over water spray (control). The plant height, chlorophyll as SPAD value, LAI increased with crop growth and declined at grain filling except for plant height, irrespective of treatments.

Table 1.Growth attributes of rice as influenced by the foliar application of water-soluble fertilizers

\begin{tabular}{|c|c|c|c|c|c|c|c|c|}
\hline \multirow[b]{2}{*}{ Treatments } & \multicolumn{4}{|c|}{ Plant height $(\mathrm{cm})$} & \multicolumn{4}{|c|}{ Total chlorophyll (SPAD Reading) } \\
\hline & $\begin{array}{r}\text { Active } \\
\text { tillering }\end{array}$ & $\begin{array}{r}\text { Panicle } \\
\text { initiation }\end{array}$ & $\begin{array}{r}50 \% \\
\text { Flowering }\end{array}$ & $\begin{array}{l}\text { Grain } \\
\text { filling }\end{array}$ & $\begin{array}{r}\text { Active } \\
\text { tillering }\end{array}$ & $\begin{array}{r}\text { Panicle } \\
\text { initiation }\end{array}$ & $\begin{array}{r}50 \% \\
\text { Flowering }\end{array}$ & Grain Filling \\
\hline$T_{1}$ & 38.2 & 73.5 & 83.4 & 96.5 & 38.6 & 40.9 & 40.8 & 38.6 \\
\hline $\mathrm{T}_{2}$ & 40.5 & 75.6 & 87.1 & 97.6 & 40.1 & 42.5 & 42.7 & 39.0 \\
\hline $\mathrm{T}_{3}$ & 42.3 & 78.5 & 88.8 & 100.9 & 43.3 & 44.1 & 44.1 & 40.2 \\
\hline $\mathrm{T}_{4}$ & 41.0 & 76.5 & 87.6 & 98.2 & 41.5 & 43.1 & 43.2 & 39.5 \\
\hline $\mathrm{T}_{5}$ & 43.0 & 78.9 & 89.2 & 101.8 & 43.9 & 44.8 & 45.1 & 40.9 \\
\hline $\mathrm{T}_{6}$ & 44.0 & 79.0 & 90.0 & 102.5 & 44.2 & 45.1 & 45.5 & 41.5 \\
\hline $\mathrm{T}_{7}$ & 44.5 & 79.6 & 91.5 & 103.5 & 44.9 & 45.6 & 46.5 & 42.5 \\
\hline $\mathrm{T}_{8}$ & 45.2 & 80.9 & 92.8 & 104.5 & 45.6 & 46.7 & 47.5 & 44.2 \\
\hline $\mathrm{T}_{9}$ & 44.7 & 79.8 & 92.0 & 103.9 & 45.2 & 45.9 & 46.8 & 43.1 \\
\hline $\mathrm{T}_{10}$ & 45.8 & 81.2 & 93.5 & 105.6 & 45.7 & 46.8 & 48.6 & 44.5 \\
\hline $\mathrm{T}_{11}$ & 35.0 & 71.0 & 81.0 & 92.5 & 35.5 & 37.6 & 35.7 & 33.3 \\
\hline $\mathrm{SE}_{\mathrm{d}}$ & 0.9 & 1.8 & 1.9 & 2.2 & 1.0 & 0.9 & 0.9 & 0.9 \\
\hline $\mathrm{CD}(\mathrm{p}<0.05)$ & 1.9 & 3.8 & 3.9 & 4.7 & 2.1 & 1.9 & 2.0 & 1.9 \\
\hline
\end{tabular}

$\mathrm{T}_{1}$ 100\% RDF +1\% Urea + 2\% MAP + 1\% KCl FS, T $) 100 \%$ RDF + 19:19:19 @ 1\% FS (Commercially available), $\left.\mathrm{T}_{3}\right) 100 \%$ RDF + 19:19:19 @ 2\% FS (Commercially available ), $\left.T_{4}\right) 100 \%$ RDF + TNAU WSF 19:19:19 @ 1\% FS, $\left.T_{5}\right) 100 \%$ RDF + TNAU WSF 19:19:19 @ 2\% FS, $T_{6}$ ) 100\% RDF + TNAU Liquid multi micronutrient @ 1\% FS, T $) 100 \%$ RDF + 19:19:19 @ 1\% (Commercially available) + TNAU Liquid multi micronutrient @ 1\% FS , T 8 )100\% RDF + 19:19:19 @ 2\% (Commercially available) + TNAU Liquid multi micronutrient @ 1\% FS, T 9 ) 100\% RDF + TNAU WSF 19:19:19 @ 1\% + TNAU Liquid multi micronutrient @ 1\% FS, T 10 ) 100\% RDF + TNAU WSF 19:19:19 @ 2\% + TNAU Liquid multi micronutrient @ 1\% FS, $\mathrm{T}_{11}$ ) Absolute control (WS)

Among the treatments tried, at all stages, foliar feeding of $100 \%$ RDF + foliar nutrition of TNAU WSF 19:19:19 @ 2\% + TNAU Liquid Multi
Micronutrient (TNAU-LMM) @ 1\% $\left(\mathrm{T}_{10}\right)$ registered the tallest plant 45.8, 81.2, 93.5 and $105.6 \mathrm{~cm}$ at active tillering, panicle initiation 50\% Flowering 
and grain filling respectively. It was comparable with $\mathrm{T}_{8}$ (100\% RDF + commercially available 19:19:19 @ 2\% + TNAU Liquid Multi Micronutrient @ 1\%), $\mathrm{T}_{9}(100 \%$ RDF + TNAU WSF 19:19:19 @ 1\% + TNAU Liquid Multi Micronutrient @ 1\%), T (100\% RDF + commercially available 19:19:19 @ 1\% + TNAU Liquid Multi Micronutrient @ 1\% ) and $\mathrm{T}_{6}(100 \%$ RDF + TNAU Liquid multi micronutrient @ 1\%) at active tillering and 50\%flowering stage and $\mathrm{T}_{8}(100 \%$ RDF + commercially available 19:19:19 @ 2\% + TNAU
Liquid Multi Micronutrient @ 1\% ), T $(100 \%$ RDF + TNAU WSF 19:19:19 @ 1\% + TNAU Liquid Multi Micronutrient @ 1\%), T (100\% RDF + commercially available 19:19:19 @ 1\% + TNAU Liquid Multi Micronutrient @ 1\% ), T6 $(100 \%$ RDF + TNAU Liquid multi micronutrient @ 1\%) $\mathrm{T}_{5}(100 \%$ RDF + TNAU WSF 19:19:19 @ 2\% ) and $\mathrm{T}_{3}$ (100\% RDF + Commercially available 19:19:19 @ 2\%) at panicle initiation and grain filling stages.

Table 2. Influence of foliar application of water-soluble fertilizers on Leaf area index and No of tillers $\mathbf{m}^{-2}$

\begin{tabular}{|c|c|c|c|c|c|}
\hline \multirow[b]{2}{*}{ Treatments } & \multicolumn{4}{|c|}{ Leaf Area Index } & \multirow[b]{2}{*}{$\begin{array}{c}\text { No.of } \\
\text { tillers } \mathrm{m}^{-2}\end{array}$} \\
\hline & $\begin{array}{r}\text { Active } \\
\text { tillering }\end{array}$ & $\begin{array}{r}\text { Panicle } \\
\text { initiation }\end{array}$ & $\begin{array}{r}50 \% \\
\text { Flowering } \\
\end{array}$ & $\begin{array}{l}\text { Grain } \\
\text { filling }\end{array}$ & \\
\hline $\mathrm{T}_{1} \quad 100 \% \mathrm{RDF}+1 \%$ Urea $+2 \% \mathrm{MAP}+1 \% \mathrm{KCl} F \mathrm{~S}$ & 1.18 & 3.21 & 3.45 & 1.52 & 304 \\
\hline $\mathrm{T}_{2} 100 \% \mathrm{RDF}+19: 19: 19 @ 1 \% \mathrm{FS}(\mathrm{CA}) \mathrm{V}$ & 1.24 & 3.61 & 3.82 & 1.61 & 320 \\
\hline $\mathrm{T}_{3} 100 \% \mathrm{RDF}+19: 19: 19 @ 2 \% \mathrm{FS}(\mathrm{CA})$ & 1.31 & 5.11 & 4.41 & 2.32 & 336 \\
\hline $\mathrm{T}_{4} 100 \%$ RDF + TNAU WSF 19:19:19 @ 1\% FS & 1.29 & 4.02 & 3.91 & 1.91 & 320 \\
\hline$T_{5} 100 \%$ RDF + TNAU WSF 19:19:19 @ 2\% FS & 1.35 & 5.52 & 4.81 & 2.56 & 352 \\
\hline $\mathrm{T}_{6} 100 \%$ RDF + TNAU LMM @ 1\% FS & 1.36 & 6.01 & 4.99 & 2.82 & 368 \\
\hline$T_{7} 100 \%$ RDF + 19:19:19 @ 1\% (CA) + TNAU LMM @ 1\% FS & 1.43 & 7.01 & 5.42 & 3.02 & 368 \\
\hline $\mathrm{T}_{8} 100 \% \mathrm{RDF}+19: 19: 19 @ 2 \%(\mathrm{CA})+$ TNAU LMM @ 1\% FS & 2.60 & 7.90 & 6.01 & 3.68 & 384 \\
\hline T $100 \%$ RDF+TNAU WSF 19:19:19@1\% + TNAU LMM @ 1\% FS) & 1.53 & 7.60 & 5.83 & 3.41 & 368 \\
\hline$T_{10} 100 \%$ RDF + TNAU WSF 19:19:19 @ 2\% + TNAU LMM @ 1\% FS & 3.01 & 8.10 & 6.72 & 3.92 & 384 \\
\hline $\mathrm{T}_{11}$ Absolute control (WS) & 1.05 & 3.03 & 3.20 & 1.01 & 224 \\
\hline $\mathrm{SE}_{\mathrm{d}}$ & 0.03 & 0.14 & 0.12 & 0.06 & 7 \\
\hline $\mathrm{CD}(\mathrm{p}<0.05)$ & 0.05 & 0.28 & 0.24 & 0.12 & 14 \\
\hline
\end{tabular}

CA- Commercial available, FS- Foliar spray, LMM -Liquid multi Micronutrient

The stature of the plants leads to structure and capacities to capture sunlight to assimilate photosynthates by more leaves. As a plant grows taller, there are better possibilities to have more effective leaves. This was confirmed in the present study that there was a significant positive correlation existed between plant height and LAI $(r=0.972 * *)$ and with total chlorophyll $(r=0.974 * *)$.

Table 3. Yield attributes of rice as influenced by the foliar application of water soluble fertilizers

\begin{tabular}{|c|c|c|c|c|c|c|}
\hline Treatments & $\begin{array}{r}\text { No. of } \\
\text { panicles } \\
/ \mathrm{m}^{2}\end{array}$ & $\begin{array}{l}\text { No. of } \\
\text { grains/ } \\
\text { panicle }\end{array}$ & $\begin{array}{r}\text { No. of } \\
\text { filled } \\
\text { grains/ } \\
\text { panicle }\end{array}$ & $\begin{array}{r}\text { Panicle } \\
\text { length } \\
(\mathrm{cm})\end{array}$ & $\begin{array}{l}1000 \text { grain } \\
\text { weight (g) }\end{array}$ & $\begin{array}{r}\text { \% chaffy } \\
\text { grains }\end{array}$ \\
\hline $\mathrm{T}_{1} 100 \% \mathrm{RDF}+1 \%$ Urea $+2 \% \mathrm{MAP}+1 \% \mathrm{KCl} \mathrm{FS}$ & 240 & 153 & 134 & 25.1 & 15.1 & 12.4 \\
\hline $\mathrm{T}_{2} 100 \% \mathrm{RDF}+19: 19: 19 @ 1 \% \mathrm{FS}(\mathrm{CA})$ & 256 & 164 & 145 & 25.2 & 15.2 & 11.7 \\
\hline $\mathrm{T}_{3} 100 \% \mathrm{RDF}+19: 19: 19 @ 2 \% \mathrm{FS}(\mathrm{CA})$ & 288 & 173 & 154 & 25.4 & 15.3 & 10.9 \\
\hline $\mathrm{T}_{4} 100 \%$ RDF + TNAU WSF 19:19:19 @ 1\% FS & 272 & 167 & 148 & 25.3 & 15.2 & 11.4 \\
\hline $\mathrm{T}_{5} 100 \%$ RDF + TNAU WSF 19:19:19 @ 2\% FS & 304 & 177 & 158 & 25.6 & 15.3 & 10.7 \\
\hline $\mathrm{T}_{6} 100 \%$ RDF + TNAU LMM @ 1\% FS & 320 & 180 & 162 & 25.7 & 15.4 & 10.2 \\
\hline $\mathrm{T}_{7}$ 100\% RDF + 19:19:19 @ 1\% (CA) +TNAU LMM @ 1\% FS & 336 & 183 & 165 & 25.7 & 15.4 & 9.9 \\
\hline $\mathrm{T}_{8} 100 \%$ RDF + 19:19:19 @ 2\% (CA) +TNAU LMM @ 1\% FS & 352 & 195 & 177 & 25.9 & 15.5 & 9.4 \\
\hline $\mathrm{T}_{9}$ 100\% RDF + TNAU WSF 19:19:19@1\% + TNAU LMM @ 1\% FS & 336 & 185 & 167 & 25.8 & 15.4 & 9.7 \\
\hline $\mathrm{T}_{10} 100 \%$ RDF + TNAU WSF 19:19:19 @ 2\% + TNAU LMM @ 1\% FS & 352 & 198 & 180 & 25.9 & 15.5 & 9.1 \\
\hline $\mathrm{T}_{11}$ Absolute control (WS) & 160 & 142 & 123 & 23.0 & 15.0 & 13.4 \\
\hline $\mathrm{SE}_{\mathrm{d}}$ & 6 & 4 & 3 & 0.5 & 0.3 & 0.2 \\
\hline$C D(p<0.05)$ & 12 & 8 & 7 & 1.0 & NS & 0.5 \\
\hline
\end{tabular}

CA- Commercial available, FS- Foliar spray, LMM - Liquid multi Micronutrient

Higher plant height might be attributed to foliar application of nutrients for proper nourishment of crop and optimum growth and also increased the activity of meristematic cell and cell elongation with the application of nutrients as they are known to have favorable effects on metabolic process and 
better vegetative growth. The results were in harmony with the results reported by Jagathjothi et al. (2012).

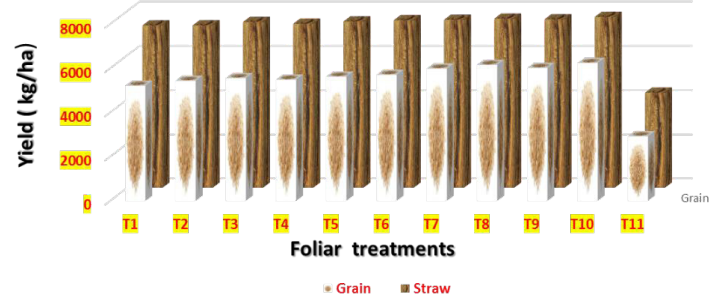

Figure 1. Effect of foliar feeding of water soluble fertilizers on rice yield

Chlorophyll coloration is related to the amount of nutrients absorbed by the plant from soil. Chlorophyll content in rice leaves was maximum (45.7, 46.8, 48.6 and 44.5 as SPAD reading) at active tillering, panicle initiation 50\% Flowering and grain filling respectively was bestowed with foliar feeding of 100\% RDF + foliar nutrition of TNAU WSF 19:19:19 @ 2\% + TNAU Liquid Multi Micronutrient (TNAU-LMM) @ 1\% $\left(\mathrm{T}_{10}\right)$. It was on par with $\mathrm{T}_{8}(100 \%$ RDF + commercially available 19:19:19 @ 2\% + TNAU Liquid Multi Micronutrient @ 1\%), T $(100 \%$ RDF + TNAU WSF 19:19:19 @ 1\% + TNAU Liquid Multi Micronutrient @ 1\%), $\mathrm{T}_{7}$ (100\% RDF + commercially available 19:19:19 @ 1\% + TNAU Liquid Multi Micronutrient @ 1\%) and $\mathrm{T}_{6}(100 \%$ RDF + TNAU Liquid multi micronutrient @ $1 \%)$ at active tillering and panicle initiation stages and $\mathrm{T}_{8}(100 \% \mathrm{RDF}+$ commercially available 19:19:19 @ 2\% + TNAU Liquid Multi Micronutrient @ 1\%), $\mathrm{T}_{9}(100 \%$ RDF + TNAU WSF 19:19:19 @ 1\% + TNAU Liquid multi micronutrient @ 1\%) at 50\% flowering and grain filling stages. This increase in chlorophyll content might be attributed to the balanced supply of nutrients at different growth stages. Similar trend was seen with Hashem (2019).

Increased leaf area has implications for light interception and DMP to support plant growth and yield (Vijayakumar et al., 2005). To achieve high yield, the maximization of the leaf area is an essential factor of the crop (Singh and Agrawal, 2010). In the present study, maximum leaf area index in rice (3.01, 8.10, 6.72 and 3.92) at active tillering, panicle initiation $50 \%$ flowering and grain filling, respectively was noticed with foliar feeding of 100\% RDF + foliar nutrition of TNAU WSF 19:19:19 @ 2\% + TNAU Liquid Multi Micronutrient (TNAU-LMM) @ 1\% $\left(\mathrm{T}_{10}\right)$. It was comparable with $\mathrm{T}_{8}(100 \% \mathrm{RDF}+$ commercially available 19:19:19 @ 2\% + TNAU Liquid Multi Micronutrient @ 1\%) at the panicle initiation stage, while at other stages, it was superior to rest of the treatments. A progressive increment of LAl of the crop up to certain days maybe because the addition of nitrogen triggers an increased number of leaves per plant and expansion of individual leaf. The increase in leaf number as well as size due to enough nutrition can be expected in terms of a possible increase in nutrition absorption capacity of the variety through better root development and increased translocation of carbohydrates from source to growing grain (Singh and Agrawal, 2010). This might be due to the development of efficient photosynthetic systems, which enabled the plant to intercept a higher amount of radiant energy which is linked to higher dry matter accumulation per plant. This increase might be due to an increase in nitrogen, being the most important plant nutrient, plays a vital role in plant photosynthesis and biomass production, and also influenced cell division and cell elongation. The same trend was observed by Okasha et al. (2019) and Jagathjothi et al. (2012). The increased photosynthetic pigment efficiency also can contribute to higher LAI, and it is confirmed in the present study through a significant positive correlation between chlorophyll and LAI $(r=0.946 * *)$.

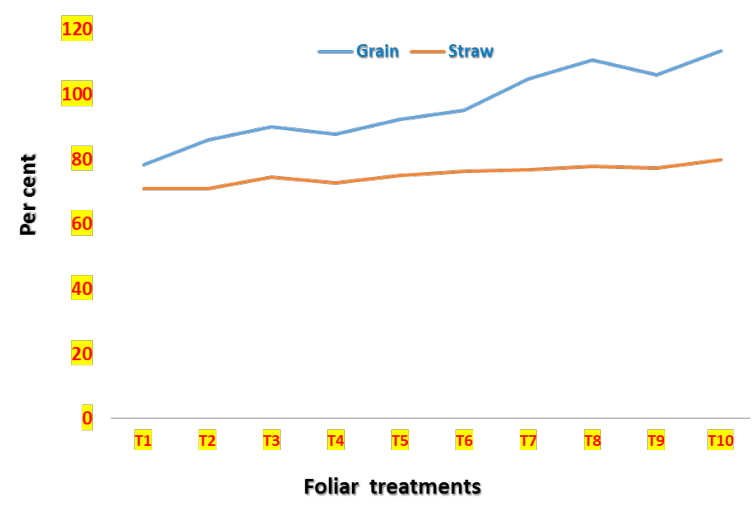

Figure 2. Percent increase in rice yield over control due to foliar feeding of water soluble fertilizers

Among the foliar nutrition treatments, maximum tiller $\mathrm{m}^{-2}$ (384) was recorded in rice plots which received foliar feeding of 100\% RDF + foliar nutrition of TNAU WSF 19:19:19 @ 2\% + TNAU Liquid Multi Micronutrient (TNAU-LMM) @ 1\% $\left(\mathrm{T}_{10}\right)$, and it was superior to rest of treatments. Tillering capacity was hindered in rice plants, which did not receive any of the major nutrients in the fertilizer schedule. Higher tillering is due to favorable root growth and higher mobility of nitrogen in soil solution and its absorption by plant roots. Phosphorus is important for plant growth and promotes root development and tillering. $\mathrm{K}$ application was also found effective in producing a prolific root system that might have able to supply adequate potassium to plant in turn improved tiller count. Similar results have been reported by Jagathjothi et al. (2012) and Hashem (2019).

\section{Yield attributes}

The yield attributes such as the number of panicles $\mathrm{m}^{-2}$, number of grains panicle ${ }^{-1}$, panicle 
length, number of filled grains panicle ${ }^{-1}$ and 1000 grain weight were influenced by various foliar treatments compared to control (Table 3). All these parameters attained highest values with $\mathrm{T}_{10}(100 \%$ RDF + TNAU WSF 19:19:19 @ 2\% + TNAU Liquid Multi Micronutrient @ 1\%). It was comparable with $\mathrm{T}_{8}$ concerning the number of panicles $\mathrm{m}^{-2}$, number of grains panicle ${ }^{-1}$, number of filled grains panicle ${ }^{-1}$, and it was on par with all treatments concerning 1000 grain weight and panicle length. An increase in yield components is associated with better nutrition, plant growth, and increased nutrient uptake. In rice, sink lies in panicle and grains, and the effect of major nutrients, particularly $\mathrm{N}$ on yield attributes, is primarily a function of assimilates accumulation and, in turn, facilitating higher $\mathrm{N}$ assimilation with an adequate supply of photosynthates to grain (Pramanik and Bera, 2013). Effective translocation of assimilates to the sink might have resulted in the sound filling of grains as revealed by the highest number of filled grains panicle ${ }^{-1}$ (Bouman et al., 2006). De Datta (1981) documented that phosphate plays an important role in converting tiller to effective tiller. Ishizuka (1971) opined that phosphorus plays an important role in the translocation of assimilates to the panicles and also as a constituent of protoplasm. This explains the reason for the increased length of the panicle and number of grains per panicle. Hasanuzzaman et al. (2012) reported an increase in yield attributes to P supply to rice soil. Potassium nutrition improves the germination of pollen in the floret, which leads to high spikelet fertility in rice (Dobermann et al., 1998). The cumulative effect of increased translocation of photosynthesis to sink by potassium enhanced yield components (Rao et al., 2004). Zinc application improved the nutritional environment of the rhizosphere as well as the plant system as evident from greater uptake of nutrients and, ultimately, metabolic and photosynthetic activity resulting in better development of yield attributes (Khan et al., 2012; Nadeem et al., 2015).

\section{Rice yield}

Statistical analyses $(p<=0.05)$ depicted in figure 1 proclaimed the significant promotional effect of various foliar feeding treatments on rice yield over water spray. The yield response ranged from 2288 to $3313 \mathrm{~kg} \mathrm{ha}^{-1}$, and percent improvement (fig 2) ranged from 78.35 to 113.5 due to different treatments. Among the foliar feeding, the maximum grain yield $\left(6233 \mathrm{~kg} \mathrm{ha}^{-1}\right)$, straw yield $(7730 \mathrm{~kg}$ ha $\left.{ }^{1}\right)$ and harvest index (0.45) was noticed with $100 \%$ RDF + foliar spray of TNAU WSF 19:19:19 @ 2\% + TNAU LMM @ 1\% ( $\left.\mathrm{T}_{10}\right)$ and was on par with $\mathrm{T}_{8}(100 \%$ RDF + commercially available 19:19:19 @ 2\% + TNAU Liquid Multi Micronutrient @ 1\%), T $(100 \%$ RDF + TNAU WSF 19:19:19 @ 1\% + TNAU Liquid multi micronutrient @ 1\%) and $\mathrm{T}_{7}(100 \%$ RDF + commercially available 19:19:19 @ 1\% + TNAU Liquid Multi Micronutrient @ 1\%). An increase in grain yield might be attributed to improvement in plant height, LAl and chlorophyll, which is due to better partition of carbohydrate from leaf to reproductive part (Yoshida, 1972). Greater LAI causes higher light interception, which further enhances GCR, RGR, and NAR and results in higher yield. The explanation is adequately supported by the significant positive correlation noticed in the present study between grain yield with plant height $(r=0.881 * *)$, chlorophyll $(r=0.945 * *)$, and LAI $(r=0.791 * *)$. As yield is the manifestation of the individual yield components, foliar nutrition increased the yield due to improvement in yield attributes. In the present study, different yield attributes showed close association with grain yield, number of panicle $\mathrm{m}^{-2}(\mathrm{r}=0.957 * *)$, number of grains/panicle ( $r=0.859), 1000$ grain weight $(r=0.845 * *)$ and panicle length $(r=0.994 * *)$. An adequate supply of $\mathrm{N}, \mathrm{P}$, and $\mathrm{K}$ through foliar application would have increased its uptake and increased the dry matter. These results are in confirmation with the results of Rabin et al. (2016) Okasha et al. (2019), Begum et al. (2018), and Hashem (2019).

\section{CONCLUSION}

This study concluded that application of fertilizers based on the STCR recommendations combined with the foliar spray of TNAU WSF 19:19:19 @ 2\% + TNAU Liquid Multi Micronutrient @ 1\% at active tillering, panicle initiation, 50\% flowering and harvest stage had increased the growth parameters and yield of rice to a tune of 19.7 percent over regular practice $\left(T_{1}\right)$.

\section{REFERENCES}

Asija, G., and Subbiah, B. 1956. A rapid procedure for the estimation of available nitrogen in soils. Curr. Sci., 25: 259-260.

Begum, Y., Patil, R., Meena, M., and Amaregouda, A. 2018. Effect of foliar and soil application of different agrochemicals on phenology, physiological parameters and productivity of rice (Oryza sativa L.). Journal of Pharmacognosy Phytochemistry. 7: 2947-2952.

Bouman, B., Yang, X., Wang, H., Wang, Z., Zhao, J., and Chen, B. 2006. Performance of aerobic rice varieties under irrigated conditions in North China. Field Crops Research. 97: 53-65.

De Datta, S. 1981. Mineral nutrition and fertilizer management of rice. Principles of Rice Production. 348-420.

Dobermann, A., Cassman, K., Mamaril, C., and Sheehy, J. 1998. Management of phosphorus, potassium, and sulfur in intensive, irrigated lowland rice. Field Crops Research. 56: 113-138. 
Hasanuzzaman, M., Ali, M., Karim, M., Masum, S., and Mahmud, J. 2012. Response of hybrid rice to different levels of nitrogen and phosphorus. International Research Journal of Applied Basic Sciences. 3: 2522-2528.

Hashem, I. 2019. Studies on the Effect of Foliar Fertilizer Application in Combination with Conventional Fertilizers on Rice Production. Journal of Plant Production. 10: 447-452.

Ishizuka, Y. (1971). Physiology of the rice plant. In Advances in Agronomy 23: 241-315. Elsevier.

Jackson, M. 1973. Soil chemical Analysis prentice hall of India Ltd. New Delhi. 219-221.

Jagathjothi, N., Muthukrishnan, P., and Amanullah, M. 2012. Influence of foliar nutrition on growth and yield of transplanted rice. Madras Agricultural Journal. 99: 275-278.

Khan, P., Memon, M. Y., Imtiaz, M., Depar, N., Aslam, M., Memon, M.S., and Shah, J.A. 2012. Determining the zinc requirements of rice genotype Sarshar evolved at NIA, Tandojam. Sarhad Journal of Agriculture. 28: 1-7.

Ladha, J., Tirol-Padre, A., Reddy, C., Cassman, K., Verma, S., Powlson, D., Van Kessel, C., Richter, D. D. B., Chakraborty, D., and Pathak, H. 2016. Global nitrogen budgets in cereals: A 50-year assessment for maize, rice and wheat production systems. Nature. 6: 1-9.

Mudalagiriyappa, Ali, M.S., Ramachandrappa, B.K., Nagaraju, and Shankaralingappa, B.C. 2016. Effect of foliar application of water soluble fertilizers on growth, yield and. economics of chickpea (Cicer arietinum L.). Legume Research. 39: 610613. doi:10.18805/Ir.vOiOF.9393

Nadeem, F., Ahmad, R., Rehmani, M.I.A., Ali, A., Alias, M., Bukhsh, H. and lqbal, J. 2015. Response of Basmati rice (Oryza sativa L.) yield to time of application of phosphorus in combination with zinc under anaerobic. International Journal of Advanced Research in Biological Sciences. 2: 2348-8069.

Okasha, A.M., Abbelhameed, M., and Elshayb, O. M. J.J.O.P.P. 2019. Improving Rice Grain Quality and Yield of Giza 179 Rice Cultivar Using some Chemical Foliar Spray at Late Growth Stages under Salt Stress. Journal of Plant Production. 10: $769-775$.
Olsen, S.R. (1954). Estimation of available phosphorus in soils by extraction with sodium bicarbonate: US Department of Agriculture.

Palaniswamy, K., and Gomez, K.J. a. J. 1974. LengthWidth Method for Estimating Leaf Area of Rice 1. 66: 430-433.

Piper, C. 1966. Soil and plant analysis 4th edition Inter Science Publishers. New York.

Pramanik, K., and Bera, A. 2013. Effect of seedling age and nitrogen fertilizer on growth, chlorophyll content, yield and economics of hybrid rice (Oryza sativa L.). International Journal of Agronomy Plant Production. 4: 3489-3499.

Rabin, M.H., Razzaque, M.A., Zamil, S.S., Zaman, A., and Siddik, A. 2016. Foliar application of urea and magic growth liquid fertilizer on the yield and nutrient content of aman rice cultivars. AmericanEurasian Journal of Agriculture and Environmental Sciences. 16: 737-743.

Rao, K., Surekha, K., Kundu, D. and Prasad, A. (2004). Nutrient management to sustain productivity targets of irrigated rice. Paper presented at the International Symposium on Rice: From Green Revolution to Gene Revolution.

Ricepedia, C., and Irri, P. (2018). Rice as a Crop. In.

Singh, R. and Agrawal, M. 2010. Biochemical and physiological responses of rice (Oryza sativa L.) grown on different sewage sludge amendments rates. Bulletin of Environmental Contamination and Toxicology. 84: 606-612.

Stanford, G., English, L., Comstock, R., Robinson, H. and Harvey, P. 1949. 2607201. Use of the flame photometer in rapid soil tests for $\mathrm{K}$ and $\mathrm{Ca}$. Agronomy Journal. 41: 446-447.

Vijayakumar, M., Sundar Singh, S., Prabhakaran, N. and Thiyagarajan, T. 2005. Effect of SRI (System of Rice Intensification) practices on the yield attributes, yield and water productivity of rice (Oryza sativa L.). Acta Agronomica Hungarica. 52: 399-408.

Yoshida, S. 1972. Physiological aspects of grain yield. Annual review of plant physiology. 23: 437-464. 